\title{
The Effect of Linguistics on Translation Studies (in 1950s-1960s)
}

\author{
Anahita Amirshoja'i \\ Higher Education Complex of Bam, Bam, Iran
}

\author{
Mohammad Hossein Ghoreishi \\ University of Birjand, Birjand, Iran
}

\begin{abstract}
Twentieth-century translation theories reveal a much expanded range of fields reflecting the differentiation of modern culture. In this regard, this paper tries to make a systematic analysis of translation studies, by examining the implication of linguistic factors in translation and determining fundamental theories of translation raised by linguistics during the 1950s and 1960s. The key notions are meaning, equivalence, and shift, with the hegemony of structural and generative transformational linguistics, and the works of some prominent linguists. At the same time, it shows that how translation was drawn into a more scientific era by elaborating on the work of American linguist Eugene Nida (1964), drawing on concepts proposed by Chomsky. Finally, based on theoretical source material, it comes to the conclusion that how linguistics was incorporated within translation theories and was drawn into a modern era as a distinct discipline.
\end{abstract}

Keywords: equivalence, linguistics, meaning, shift, systematic analysis, translation

\section{Introduction}

In this paper, the emphasis has been put on the variety of linguistic approaches to the analysis of translation to answer the question that how linguistics was put at the service of translation, making it more systematic and scientific. In this regard, detailed lists and taxonomies have been proposed, so as to classify translation's models based on systematic and linguistic oriented analysis. The significant implication of linguistics on translation theories can be revealed through the work of some scholars and linguists in the field of translation, and its inherent correlation and interrelation with translation.

To know that whether translation is an activity based on different scientific theories, Joseph F. Graham in his article "Theory for Translation" (1981, p. 24) asks the question if the time-honored act of translation really is a subject that begs to be theorized (as cited in Hodges, 2009). Taking this matter into account and based on theoretical approaches and scientific works of other scholars like: Munday, Malone, Venuti, Hatim, and Gentzler, this paper shows that how theoreticians in the 1950s and 1960s began to make a more systematic analysis of translation, after centuries of debate around literal and free translation. This systematic analysis, according to Munday (2001, p. 126), has elevated translation studies from its role of being primarily a language learning activity, and has centered on theories of translation in new linguistic, literary, cultural, and philosophical context. However, it is the linguistic context which is the main focus of this paper based on scientific theories and works of some prominent linguists during these two decades.

Anahita Amirshoja'i, lecturer, M.A., English Department, Higher Education Complex of Bam. 


\section{Historical Background}

Early attempt at translation studies can be traced back over 2,000 years around the key notions of literal and free approach (Hodges, 2009). Venuti (2004) asserted that these varying sets of terms derive from traditional dichotomies between "sense-for-sense" and "word-for-word" translating which date back to antiquity, to Cicero and Horace, Jerome and Augustine (as cited in Venuti, 2000, p. 148). This is the area which Newmark calls the pre-linguistic period of translation (Munday, 2001, p. 18).

According to Kelly (1979), the Jewish scholars who translated the old testament had no interest in theory, because they never anticipated any controversy over the issue of translating the Holy scriptures, no intent or structure besides those of the Holy Scriptures could be of any value, because they were God's words, and since human beings were in reality in an inferior position, no discussion on the relationship between objects and symbols was deemed to be possible (Miremadi, 1995, p. 49).

In Machan's view, what made the evaluation of translating developments in this era difficult was the fact that, either no theory was or even could be available, or if, by any chance, there was a theory, the translators themselves refused to express the techniques and their goals explicitly (Miremadi, 1995, p. 50).

According to Graham quoted in Gentzler (1993): "Most studies about translation were theoretically weak, containing common place which could not account for a unified theory for translation” (p. 59). Gentzler (1993, p. 59) argued that even the American translation workshop was lacking theories and systematic approaches while early attempts on systematic translation theories had been made by Dryden, Dolet, and Tytler, which marked the beginning of a more systematic and precise definition of translation (Munday, 2001, p. 33), the debate over literal and free translation went on up to the second half of the 20th century when the need for more systematic analysis of translation was quite apparent, and the only discipline which comprised adequate theoretical and lingual frameworks for handling the above mentioned dichotomies, was linguistics (Gentzler, 1993, p. 59).

So, it can be said that translation owes its systematic analysis to linguistics and to the work of some prominent western European theoreticians. This view was challenged by two groups: structuralist, and functionalist, or followers of contextual model who believed that language was not just about structure, it was also about the way language is used in a social context (Miremadi, 1995, p. 155).

Since handling both the groups is beyond the scope of this paper, and as the modern translation theories commenced with the structuralism era: The main focus of this article is on structural linguistics with the works of some prominent scholars, i.e., Jakobson, Nida, Vinay and Darbelent, and Catford during the 1950s and 1960s, with the emphasis on meaning, equivalence and shift.

\section{Chronological Analysis}

\section{Roman Jakobson (1959) (Meaning and Equivalence)}

Russell's well-known statement that "no one can understand the word 'cheese' unless he has a non-linguistic acquaintance with cheese" has been elaborated by Jakobson (1959) by stating that: "No one can understand 'cheese' unless he has acquaintance with the meaning assigned to this word in the lexical code of English” (p. 138).

Three kinds of translation were to be differently labeled by Russian-American structuralist Jakobson in his seminal paper "On Linguistic Aspect of Translation”: (1) intralingual; (2) interlingual; and (3) 
intersemiotic (as cited in Munday, 2001, p. 5). According to Jakobson, the intralingual translation of a word uses either another, more or less synonymous word or resorts to a circumlocution. Likewise, on the level of interlingual translation, there is ordinarily no full equivalence between code-unites. For him, meaning and equivalence are linked to interlingual form of translation. However, according to Nida, the main problem with this categorization is that language has been considered as a code, whereas language is a network of communicative events (as cited in Miremadi, 1995, p. 129).

Jakobson (1959) argued that, however, most frequently translation from one language into another, substitutes messages in one language not for separate code-units, but for entire messages in some other language. In his view, such a translation is a kind of reported speech: "The translator recodes and transmits a message received from another source. Thus translation involves two equivalent messages in two different codes" (Jakobson, 1959, p. 114).

Robinson (2003) posited that for some translators the entire purpose of translation was achieving equivalence. This equivalence as Jakobson (1959) mentioned in his paper "is the cardinal problem of language and the pivotal concern of linguistics" (p. 37). Drawing on the concept of linguistic meaning and equivalence, he follows the relation set out by Saussure between signifier and signified which form the linguistic sign (Munday, 2001, p. 36). For Jakobson, no linguistic specimen can be interpreted by the science of language with any translation of its signs into other sings of the same system or another system.

Translation theory in these decades was dominated by the fundamental issue of translatability influential figures in philosophy, literary criticism, and linguistic all consider whether translation can reconcile the differences that separate language and cultures (Venuti, 2000, p. 111). In this regard, Jakobson (1959) believed that any comparison of two languages implies the examination of their mutual translatability, he added the practice of interlingual communication, particularly translation must be kept under constant scruting by linguistic science. While Jakobson (1959) did not deny the fact that languages differ in semantics and syntactics, and strongly argued that "languages differ essentially in what they must convey not in what they may convey" (p. 141), he asserted that all of the cognitive experience and its categorization is conveyable in any existing language, and in the case of deficiency, terminology can be qualified by using loan-words or loan-translation, neologisms or semantic shifts, and finally by circumlocution (as cited in Venuti, 2000, p. 140).

Besides dealing with the notion of equivalence, meaning, and translatability, Jakobson also examines language function by means of analyzing speech events. He enumerates different functions for language: referential, emotive, conative, phatic, metalingual, and poetic function (as cited in Lotfipur Saedi, 1992, p. 14). The elaboration on these functions is beyond the scope of this paper.

Equivalence is also a preoccupation of American linguist and Bible translator, Eugene Nida.

\section{Eugene Nida (1960) (Science of Translation, Further Advances in the Notion of Meaning and Equivalence)}

Up to the beginning of the 1960s, linguistics was concerned with descriptive studies and never paid attention to the comparative ones, so there were not any significant works dealing with translation theory, the emergence of two co-extensive grammatical theories changed the direction of translation study dramatically: Chomsky's Syntactic Structure (1957) and Aspects of the Theory of Syntax (1965). Generative transformational grammar with its legitimacy in linguistics legalized Nida’s scientific work (Gentzler, 1993, p. 60). 
Nida's theory of translation developed from his practical work, form the 1940s on words when he was translating and organizing translation of Bible (Munday, 2001, p. 37). In the early 1960s, when a systematic, theory-based approach to many disciplines, including linguistics, was prominent, translation theory underwent a quantum leap with the work of Nida (Hatim, 2004, p. 34). Being aware of the lack of systematic-oriented approach in translation, Nida attempted to legitimize his own methodology (Gentzler, 1993, p. 62), by adopting some of the current theoretical notions in linguistics (notably Chomsky's linguistics), anthropology, and at the same time from semantics and pragmatics, to move translation into a more scientific era (Hatim \& Munday, 2004, p. 34). These ideas formed the basis of his Toward a Science of Translating (Nida, 1964) and The Theory and Practice of Translation (Nida \& Taber, 1969). As the title of the first book suggests, it sees translation as a science that could be analyzed systematically (Hatim \& Munday, 2004, p. 34), and one of its aims is the redefinitism of principles through which the accuracy in translation and judgment about accurate translation can be achieved (Gentzler, 1993, p. 78). Gentzler (1993, p. 61) asserted that while this book, due to its extreme examples was changed into one of theological branches, i.e., missiology, and its influence was so significant in translation.

Nevertheless, Nida's religious presupposition can be easily understood by the analysis of his other book The Theory and Practice of Translation, which had been written before his acquaintance with Chomsky (Gentzler, 1993, p. 70). Gentzler (1993, p. 62) argued that Nida's religious belief and his ideology goals can be seen implicitly within his scientific framework. Drawing on research from the American Bible society, Nida considers the problem of translating between different realities. He argues that religious message cannot be conveyed in translation due to different cultural context, so the solutions need to be ethnological base on the translator's acquisition of sufficient “cultural information” (as cited in Venuti, 2000, p. 113). Gentzler (1993, pp. 71, 79) asserted that Nida was excessively concerned about the reaction of the receiver of the message, regarding both pragmatic and religious response, so he believed that in order to convey the word of God, the word "lamb" can be translated to "seal" or "pig”, or to some other forms. In order to make the text legible for the reader, even in Bible, he tried to eliminate ambiguities and Freudian slips, to reduce the complex text to a simple one for the reader (Gentzler, 1993, p. 77).

Nida's main concern for establishing translation science was originated form his aversion of the classic revival in the 19th century. The approach that emphasized on mechanical accuracy by clinging to form and by adopting literal translation. In Nida's view, this kind of translation appeared to have snob value. In this regard, he named Arnold as a scholar whose attitude toward highly literal translation had a negative effect on Bible translation at the early 20th century (Gentzler, 1993, p. 61). So, he rejected the "free" versus "literal" debate in favor of the concept of "formal" and "dynamic" equivalence-a concept that shifts the emphasis to the target audience, to make reading and understanding of the Bible easier for people with no knowledge of it (Hodges, 2009). Formal equivalece centers on the form and content of the message of ST (source text) (Munday, 2001, p. 41), it adheres so closely to the linguistic and cultural value of the foreign text as to reveal the translation to be a translation (Venuti, 2000, p. 148). Dynamic equivalence, in contrast, later formed pragmatic equivalence (Venuti, 2000, p. 148), communicates the foreign text according to values as familiar in the receiving language and culture as to conceal the very fact of translation. It is what Munday (2001, p. 42) referred to as complete naturalness of expression in the TT (target text). 
Nida reflects all of the traditional approaches to meaning which includes: centripetal, centrifugal, and lineal concept (Miremadi, 1995, p. 130). His linguistic theory moves towards the fields of semantics and pragmatics, which leads him to development system for the analysis of meaning: (1) hierarchical structure: which differentiates series of words according to their level (superordinate and hyponym), such as hyponyms "brother" or "sister" and the superordinate "sibling"; (2) componential analysis: which identifies and discriminates specific features of a range of related words, e.g., "brother" in Afro-American talk does not necessarily refer to make relation born of the same parents; and (3) semantic structure analysis where the connotative and denotative meanings of homonyms are identical, e.g., "bat” the animal and the piece of sporting equipment (Munday, 2001, p. 38). He believes in sacrificing the form in favor of meaning.

In spite of some criticism towards Chomsky's model including ambiguity of structure (Gentzler, 1993, pp. 69, 82), lack of semantic and pragmatic component, Wills argued that generative transformational grammar has the same problems as structural linguistics, and in spite of Chomsky's dissidence, Nida and later Wills drew on the Chomsky's work (as cited in Gentzler, 1993, p. 11), calling their theoretical works a "science" of translation, giving the topic scholarly coherence and legitimacy that it has so far lacked (Venuti, 2000, p. 150). Gentzler (1993, p. 64) asserted that although Chomsky's deep and surface structures and his transformational rules are within one language, they are applicable for justifying translation theory. So, Nida simplifies Chomsky's model by reversing it when analyzing ST, providing the translation with a technique for decoding the ST and a procedure for encoding the TT. His three stage systems of translation consist of analysis, transfer, and restructure (Munday, 2001, p. 39), and the most basic structure in his model are kernel sentences. However, some criticisms have been put towards this adoption. Gentzler (1993, p. 75) argued that the reversal movement and the reduction of the text into simple structures and kernel sentences can be considered as an inaccurate correspondence of Chomsky's model, and the act of decoding, encoding is dysphemism of his model. He continues that in his simplified theory, Nida did not tell us anything about how the transfer of deep structure is viable and his proposition has nothing to do with general translation theory (as cited in Gentzler, 1993, p. 77).

Nevertheless, there are some similarities and differences regarding Nida and Chomsky's models: With regard to similarities, Gentzler (1993, p. 72) asserted that both models are abstract, and Nida's pragmatic aspect is similar to Chomsky's deep structure. According to Gentzler (1993, p. 74), although their intentions and goals are different, they both came to the same conclusion about the nature of language.

With regard to the differences, Gentzler (1993, p. 70) argued that Nida pays more attention to cultural context, while Chomsky's model was lacking in it. Theoretically, Nida gives priority to the reaction created by sign than the sign itself, while Chomsky wants to show that the sign irrespective of the cultural context contains meaning in nature (as cited in Gentzler, 1993, p. 71). In Gentzler's (1993, p. 79) view, the main differences are that Chomsky's general forms are embedded within a level deeper and more abstract than Nida's kernel structures.

Besides the above mentioned criticism related to this adoption, Nida's fiercest critics is Gentzler, as it was mentioned early in the article, which denigrates Nida's work for its theological and proselytizing standpoint with the concept that dynamic equivalence serves the purpose of converting the receptors, no matter what their culture is, to the dominant discourse and ideas of protestant Christianity (Munday, 2001, p. 43).

Anyway, within the linguistic paradigm and with equivalence as the key concept in translation studies, Nida's work on the dynamic effect has been extremely influential not only for Bible translation, but also in 
dealing with a variety of text forms for a wide range of purpose (Hatim, p. 47). Nida's systematic linguistic approach to translation has been influential on many subsequent and prominent translation scholars, among whom are peter Newmark in the UK (1981), and Werner Koller in Germany (1979).

\section{Vinay and Darbelnet, Catford (Some Hints on the Notion of Shift)}

The emphasis of structural approach to translation changed towards the end of the 1950s and early 1960s with the work of Canadian linguists Jean Paul Vinay and Jean Darelnet. By approaching French-English translation form the field of comparative stylistics, they provided a theoretical basis for a variety of translation methods (Venuti, 2000, p. 114). They elaborated on the concept of examining linguistic changes that take place between ST and TT, during translation (Munday, 2001, p. 55). Venuti (2000) asserted that "translation theories that privilege equivalence must inevitably come to terms with the existence of shift between the foreign sand translated text” (p. 148). By noting differences between the languages, they identified different translation strategies and procedures in the subsequent years. The two strategies were direct and oblique translation, comprising seven procedures: borrowing, calque, literal for direct and transposition, modulation, equivalence, and adaptation for oblique translation, later known as shift (Munday, 2001, p. 56). They produced a text book that has been a staple in translator training programs for over four decades. Their translation methods involve some reduction of linguistic and cultural differences to empiricist semantics. They also encouraged the translator to think of meaning as a cultural construction and to see a close connection between "linguistic procedures" and “metalinguistic information” (Venuti, 2000, p. 114).

However, Vinay and Darbelnet did not use the word "shift". The term itself first applied to the theory of translation by "Catford" in his famous book Linguistic Theory of Translation (1965). He follows the Firthian and Holidayan linguistic model, which analyzes language as communication, operating in context and on a range of different levels and ranks. He makes an important distinction between formal equivalence and textual correspondence (Munday, 2001, p. 60). Translation classification depicted by Catford can be summarized as: full versus partial, total versus restricted translation (Miremadi, 1995, p. 143). Later on he considers two kinds of shift: level shifts and category shifts. The latter covers structural, class, unit, and intersystem shifts (Munday, 2001, p. 61).

Catford's book is an important attempt to apply to translation advances in linguistics in a systematic fashion (Munday, 2001, p. 61). Of particular interest is Catford's assertion that translation equivalence depends on communicative features such as function, relevance, situation, and culture rather than just on formal linguistic criteria (Munday, 2001, p. 61). "Translation equivalence”, Catford asserts: “Occurs when a SL and a TL text or item are relatable to the same feature of substance”, where "substance” (as cited in Venuti, 2000, p. 151) can signify a relatively fixed range of linguistic features, levels and categories, as well as potentially infinite series of cultural situation.

The main criticism of Catfrod's book is that his examples are almost idealized and contextualized. He never looks at the whole text, nor even above the level of sentence (Munday, 2001, p. 62). Venuti (2000) asserted that the expansion of translation research in the 1960s coincides with an increased awareness that it represents on emerging academic discipline. Theorists like Catford felt that translation studies do not deserve the institutional autonomy of linguistics because they are not theorizing about language, but of applying linguistic theories (Venuti, 2000, p. 150). 


\section{Further Researches on the Notion of Shift and Equivalence}

Other writings on translation shift in the 1960s introduced by Levy. He carried out experiments showing that pragmatic translation involves a "gradual semantic shifting” that translators choose from a number of possible solutions. Modern translators, he asserts, apply the "minimax strategy”. Choosing the solution "which promises a maximum of effect with a minimum of effort” (Levy, 1967, p. 156). Elsewhere Levy is critical of the results: He finds that shifts work to generalize and clarify meaning, "changing the style of a literary work into a dry and uninspiring description of things and actions” (as cited in Venuti, 2000, p. 148).

He also synthesizes psycholinguistics, semantics, structural anthropology, literary criticism, and game theory (Venuti, 2000, p. 150).

Regarding other writings on the notion of equivalence, Mounin argues that equivalence is based on "universals" of language and culture, questioning the notion of relativity that in previous decades made translation seem impossible (as cited in Venuti, 2000, p. 14). Linguists like Mounin assume that universals bridge linguistic and cultural differences (as cited in Venuti, 2000, p. 151).

Of course other theorists have contributed to a development of linguistics to translation studies, the above-mentioned have been singled out for their influence, perhaps for being the most representative of the trends of the time (Hodges, 2009). Other linguists continue to work on equivalence but on the textual, functional, cultural, and discourse level in subsequent years, in which elaboration on them is beyond the scope of this paper.

\section{Conclusions}

As it was mentioned, the sheer proliferation of linguistic-oriented approaches in translation studies opened with the era of structuralism, and in spite of some criticisms and controversial questions in this regard, this era played a significant role in systematic analysis of translation theories, and paved the way for further researches and the status quo of translation studies. In this regard, it can be said that the study of translation as an academic discipline developed in the second half of the 20th century, and before that it had been only an element of language learning in modern language courses (Munday, 2001, p. 7).

Translation procedure is embedded in contrastive linguistics (which is one of the branches of applied linguistics); moreover, while science of linguistics is not monolithic but rather comprises a network of sub discipline traversed by a variety of analytic perspective, and not all of its facets are equally applicable to translation (Malone, 1988). It was being put at the service of translation, and translation theories have recourse to linguistics for having a monolithic system.

All in all, linguistic analysis of translation theories covers important concepts among them, meaning, equivalence, and shift have been examined in this article, along with Nida's scientific approach which turned into an attempt for a more systematic analysis of translation theories, which on Nida's term should be based on linguistics, philology, and semiotics. Nevertheless, linguistic analysis of translation theories goes beyond the above-mentioned concepts. With the emergence of modern linguistics and the emanation of Leipzig school of thought in the middle of 60 decades, the linguists' focus changed into the notion of text, its function, extra textual level, and at the wider level, on the concept of discourse, this is new and open for further discussion. 


\section{References}

Gentzler, E. (1993). Contemporary translation theories. Tehran: Hermes Publication.

Graham, J. F. (1981). Theory for translation. In G. Rose (Ed.), Translation spectrum: Essays in theory and practice (pp. 23-30). Albany: State University of New York Press.

Hatim, B., \& Munday, J. (2004). Translation: An advanced resource book. London and New York: Routledge.

Hodges, P. (2009). A linguistic approach to translation theory. In L. Venuti (Ed.), The translation studies reader (2nd ed.). London and New York: Routledge.

Jakobson, R. (1959). On linguistic aspects of translation. In L. Venuti (Ed.), The translation studies reader (2nd ed.). London and New York: Routledge.

Kelly, L. G. (1979). The true interpreter. New York: St. Martin’s.

Levy, J. (1967). Translation as decision process. In L. Venuti (Ed.), The translation studies reader (2nd ed.). London and New York: Routledge.

Lotfipur Saedi, K. (1992). An introduction to principles of translation. Tehran: Nashre Daneshgahi.

Malone, J. L. (1988). Science of linguistics in the art of translation. Albany: State University of New York Press.

Miremadi, A. (1995). Theories of translation and interpretation. Tehran: The Center for Studying and Compiling University Books in Humanities (SAMT).

Munday, J. (2001). Introducing translation studies: Theories and application. London and New York: Routledge.

Nida, E. A. (1964). Toward a science of translating. Leiden: E. J. Brill.

Robinson, D. (2003). Becoming a translator: An introduction to the theory and practice of translation (2nd ed.). London: Routledge.

Venuti, L. (2000). The translation studies reader (2nd ed.). London and New York: Routledge. 